Branimir Jovanovic

\title{
Should the Macedonian denar be devalued? Some evidence from the trade equations
}

\begin{abstract}
Recently some have reminded us of the panacea for the Macedonian economy the devaluation of the denar. We feel that the public deserves an explanation - why might devaluation help the economy and why we believe it would not help the Macedonian economy at the present moment. In theory, devaluation makes domestic products cheaper and foreign products more expensive, so it could stimulate exports and de-stimulate imports, improving the current account. In practice, however, Macedonian exports appear not to be dependent on the exchange rate, while imports appear to depend only very little. Thus, devaluing the denar is likely to have no major effect on the current account while the costs, in terms of the loss of confidence in the national currency, will be very high.
\end{abstract}

Keywords: devaluation, exchange rate, current account, trade, exports, imports, denar, Macedonia.

\section{Introduction}

Recently, in Macedonia, we have been able to hear and read about devaluation almost every day. Two of the most influential daily newspapers in Macedonia, Dnevnik and Utrinski vesnik, have been elaborating the issue quiet extensively in the last six months (July 2008-January 2009). For instance, Dnevnik has run fifteen stories mentioning devaluation in this period, which means that they have written about it more than once in a fortnight. It is even worse if you read Utrinski vesnik - there have been around one hundred articles containing 'devaluation' and 'denar' in the last six months and once even the front page was about it. Not to mention countless TV programmes.

It is easy to understand why journalists are so concerned about devaluation - they are always after bombastic stories and not many sell better than this one, especially if memories of past devaluations are fresh. Concerning who stands behind these stories again, it's simple: there are always small groups of people who can profit from such an action.

One additional factor has contributed greatly to the recent ubiquity of these stories in Macedonia: politics. An issue like this is very suitable for attacking your political opponents. But that's out of scope of this paper.

Of course, as economists, we should not care much for cheap talk. But, it is not only journalists who write about devaluation: this thesis is becoming more and more popular even among academics. The number of economists who support it, at least judging from their statements in the media, is growing. And they all present the same argu- 
ments - the high and worsening trade deficit and the declining foreign exchange reserves.

We strongly disagree with them. We disagree with the thesis that the high and worsening trade deficit is a sufficient condition for devaluation. For the devaluation to be a viable action in the current setting in Macedonia, one additional condition must be met: and that is - it has to be able to improve the trade balance. We will show that this is not likely to be the case: the exchange rate does not seem to influence trade. Thus, devaluing the denar will have no significant effect on trade, but it will have disastrous effects on the economy through a loss of confidence in the national currency.

To be clear - we are not saying that the lack of effect of the exchange rate on trade is itself a sufficient argument against devaluation. The question of the right parity of a currency is very complex and the case for or against devaluation should be made only on the grounds of the relation between the actual and the equilibrium exchange rate.

The structure of this article is as follows: in the next section, we briefly explain some basic concepts - nominal and real exchange rates; the case for devaluation; and the conditions for it to be successful. Then we present a short review of the literature on the issue, including the literature that exists concerning Macedonia. We then estimate export and import equations for Macedonia, using the OLS method; examine the robustness of these results, as well as their stability; and investigate whether cointegration methods give different results. In the penultimate section, prior to the conclusion, we discuss our findings, examining why they differ from some previous studies, and presenting the contributions of the individual factors to total exports and imports growth.

\section{Devaluation and the case for it}

The price of a national currency is called the nominal exchange rate. Similarly to other prices, the nominal exchange rate is determined by demand and supply conditions - if demand for the Macedonian denar increases, its price will tend to go up, i.e. the denar will appreciate. Being a form of money, a currency can be demanded either for transaction purposes, i.e. to pay for goods and services, or for store of value purposes. If exports of Macedonian goods increase, then, in order to pay for those goods, the demand for denars will increase and the denar will appreciate. However, if people think that a currency will depreciate in the future, they will switch their holdings away from that currency to some other, which will decrease demand and lead to depreciation.

This mechanism works for currencies with flexible exchange rate regimes, when the country lets the market determine the price of the currency; for instance, the US dollar. If the exchange rate is fixed, as is the case in Macedonia, the price of the currency cannot change - the monetary authority provides the amount of currency, either national or foreign, that is demanded at the set exchange rate. If the demand for Euros (relative to denars) increases, the central bank will have to sell Euros out of its foreign reserves in order to meet the demand for them, so the value of the denar will not change. However, with a high demand for Euros over a longer period of time, the central bank might 
sell its reserves, ${ }^{1}$ and then it will have either to make the currency float freely or to devalue it.

It was mentioned above that the demand for Euros (relative to denars) might increase basically for two reasons - if assets, both goods and financial assets, as well as services, that are paid for in Euros are purchased more than assets and services paid for in denars; and if people start using Euros, instead of denars, to store value. Right now in Macedonia, due to the worsened net export situation, i.e. increased imports and decreased exports, the demand for denars relative to Euros has decreased. This generates pressure on foreign reserves and, if this situation continues for a longer period of time, the central bank might eventually be forced to devalue the currency. In order to avoid losing reserves, the authorities might devalue the currency as a means of improving the trade balance. This is the case for devaluation.

Let us now turn to the real exchange rate. The nominal exchange rate, adjusted for inflation differentials between countries, provides the real exchange rate. For instance, the denar is pegged to the euro; with an inflation rate of $8 \%$ in Macedonia (in 2008) and $3 \%$ in the Eurozone, then the real amount of products that can be bought with the denar in Macedonia in 2008 is, compared to the previous year, $5 \%$ lower than the amount that could be bought with the euro in the Eurozone. Therefore, the real exchange rate is not a measure of the value of the domestic currency, but a measure of the domestic price level relative to abroad. Thus, if domestic inflation is higher than that abroad, this makes domestic products more expensive, i.e. the real exchange rate appreciates. If the relative price of Macedonian products is higher, demand for them falls. So, the exchange rate determines the price competitiveness of domestic products and, consequently, affects both imports and exports. It is important to note that it is the real exchange rate, not the nominal rate, that affects trade; the nominal exchange rate affects trade only indirectly, through the real exchange rate.

Thus, the arguments for devaluing the denar lie in the deteriorated net export situation: to improve net exports, the authorities might devalue the currency. This would make domestic products cheaper and foreign products more expensive; people would consequently buy more Macedonian products and the net export situation would improve. However, whether this does indeed happen depends on two conditions: how the real exchange rate reacts to a given change in the nominal exchange rate; and how imports and exports react to a change in the real exchange rate.

Regarding the first condition - how much a given change in the nominal exchange rate affects the real exchange rate - depends on the exchange rate pass-through, i.e. how domestic prices react. Nominal depreciation makes imported products more expensive; if the final prices of domestic goods depend significantly on the prices of imported intermediate products, then the real exchange rate will not change much. Studies on the exchange rate pass-through for Macedonia have indicated that consumer prices react fairly strongly to changes in the nominal exchange rate. Besimi et al. (2006) found that a unitary increase in the exchange rate increases prices by $0.4 \%$; Vrboska

1 This is a simplification of the process. Of course, the central bank will not sell all of its reserves. Rather, the reserves might reach a critical level in terms of different criteria, e.g. the coverage of imports. 
(2006) found that the exchange rate pass-through varies between 0.46 and 0.17 , depending on the horizon; while Krstevska et al. (2004) reported a lower pass-through (0.10). This means that a nominal depreciation of, say, $10 \%$ will lead to inflation of around $4 \%$ (according to Besimi et al. 2006), and a real depreciation of around $6 \%$. In other words, a particular nominal depreciation, which is what the authorities can directly achieve, will produce a real depreciation which does not reach such a level plus a degree of inflation. This is one argument against devaluation.

The second condition - how exports and imports react to a given change in the real exchange rate - is the main objective of this article. We emphasise that the primary aim of the analysis is not to estimate trade elasticities in the conventional manner. Trade elasticities show how much export and import volumes react to changes in income and prices. We want to investigate the factors that have driven the dynamics of exports and imports over the previous twelve years and, in particular, to examine whether the exchange rate has been one of them. Thus, we are more interested in export and import values (to which we return later).

\section{Literature review}

There is a vast literature on the econometric modelling of exports and imports, which makes this task relatively easy (some of the studies include Houthakker and Magee, 1969; Goldstein and Khan, 1978, 1982 and 1985; Dornbusch, 1985; Krugman, 1989; Holly and Wade, 1991; Riedel, 1984 and 1988; Muscatelli et al. 1990).

Regarding exports, two general approaches can be identified in the literature. The first of these specifies exports as a function of demand (Houthakker and Magee, 1969), assuming that supply can meet whatever quantity is demanded. However, this assumption has been questioned by Goldstein and Khan (1978), amongst others, who argue that supply conditions are just as important, especially for small countries who can affect neither the price nor the level of demand for their exports. Consequently, significant differences can be observed in the estimated trade elasticities. Most of the early studies, which neglected supply side factors, found high income elasticities in exports and low price elasticities, which would mean that export performance for a small country is exogenously determined, i.e. it depends on how well the rest of the world is doing. This would imply little scope for action. However, studies taking supply side factors into consideration generally find that supply conditions, i.e. production capacity, are an important determinant of exports. They do, however, differ regarding the importance of demand factors: some argue that demand is not important; and some argue that it is. $^{2}$

Regarding imports, things are nowhere near as complicated - almost all studies model imports as a function of demand, i.e. it is dependent on price and income. Studies might differ with regard to the variables used, but the essence is the same.

So far, there have been several studies which have investigated Macedonian exports and imports - Jovanovic (2007); Kadievska-Vojnovic and Unevska (2007); and Pe-

2 The very interesting debate on this issue can be found in Riedel (1988); Muscatelli et al. (1992); Athukorala and Riedel (1994); and Muscatelli (1994). 
treski and Jovanovic (2009). Perhaps rather strangely, in the context, their findings regarding trade elasticities differ substantially, as can be seen in Table 1.

Table 1 - Review of Macedonian trade elasticities found in the literature

\begin{tabular}{|l|l|c|c|l|}
\hline Study & & Imports & Exports & Comment \\
\hline Jovanovic (2007) & $\begin{array}{l}\text { Income } \\
\text { Price }\end{array}$ & $\begin{array}{c}2.1 \text { and } 2.5 \\
1.2 \text { and } 1.3\end{array}$ & $\begin{array}{c}1.5 \text { and } 1.6 \\
-2.2 \text { and } \\
-2.8\end{array}$ & Real exchange rate as price \\
\hline $\begin{array}{l}\text { Kadievska-Vojnovic } \\
\text { and Unevska (2007) }\end{array}$ & $\begin{array}{l}\text { Income } \\
\text { Price }\end{array}$ & $\begin{array}{c}3.5 \\
-1.6^{*}\end{array}$ & $\begin{array}{c}1.5 \\
-0.7\end{array}$ & $\begin{array}{l}\text { Relative export and import } \\
\text { prices (to domestic prices) } \\
\text { as price }\end{array}$ \\
\hline $\begin{array}{l}\text { Petreski and Jovanovic } \\
(2008)\end{array}$ & $\begin{array}{l}\text { Income } \\
\text { Price }\end{array}$ & $\begin{array}{c}1.1 \\
0\end{array}$ & $\begin{array}{c}4.7 \\
\text { Includes other variables as } \\
\text { well }\end{array}$ \\
\hline
\end{tabular}

* The sign is opposite but, due to the different definition of the variables, the direction of the effect is the same.

However surprising these differences are, it is easy to understand them - they are a consequence of the different data sources used (international financial statistics; or the State Statistical Office of Macedonia); the different ways in which the variables have been constructed (the trade weighted GDP of the biggest trading partners or the GDP of the EU-15; the real exchange rate; or export and import prices); and the different specifications of the equations (some equations also include additional variables). Nevertheless, these differences, together with the differences found in the literature and mentioned above, point to the care with which one should approach the estimation of trade equations.

\section{Empirical investigation}

\section{Data and variables}

The data and variables selected can greatly affect the quality of the research, especially for countries like Macedonia, with short time series, sometimes of questionable quality, and which are often subject to major revisions.

When modelling trade, it is common to model volumes and prices separately, i.e. trade equations are usually based on trade volumes, not values, as a function of income and price. However, in the Macedonian case, no official data exist for export and import volumes or prices after Q4 2005, which leaves us with two options - we can either try to compile export and import volumes and prices ourselves; or we can use export and import values instead. We have opted for the second alternative, for two reasons. First, we believe that everybody should do what they can do best, and we do not think that we are very experienced at data compilation. Second, we do not believe that working with values, instead of volumes, will affect the results greatly - at least, not for our purposes. Of course, the coefficients of the independent variables in the regressions will differ, but it is highly unlikely that the significance will differ. In addition, we 
doubt that there will be a difference when we interpret the variables in terms of their contribution to the growth in exports and imports. Therefore, the dependent variables in our equations are nominal exports and imports (source: State Statistical Office of Macedonia, SSOM).

The price variable used is the real effective exchange rate, compiled by the National Bank of the Republic of Macedonia, defined in such a way that an increase stands for a real appreciation. Foreign demand is the trade weighted real GDP of six major trading partners - Belgium; Germany; Greece; Spain; Italy; and Netherlands - with the weights being the normalised shares of total exports in 2006 (this is the series that the National Bank uses in its analyses for foreign demand). Domestic GDP is the figure in real terms, obtained from SSOM, as is industrial production; metals prices are from the IMF Primary Commodity Prices database (the commodity metals price index), divided by the denar/dollar nominal exchange rate so as to eliminate the effect of the depreciation of the dollar; while domestic private consumption and investment are in nominal terms (again, no official data on real consumption and investment exists for Macedonia). For the period prior to 2005, when no official quarterly data exist, these latter are calculated from the annual data, using the Chow-Lin method for interpolation.

Thus, in the final imports regression, all the variables are in nominal terms; while, in that for exports, only the export figures are nominal. All the series are seasonally adjusted except for the real exchange rate and metals prices (we do not expect seasonality in these). Variables enter the models in their logarithmic form, meaning that their coefficients represent the respective elasticities, i.e. they provide the percentage growth in the dependent variable arising from a one per cent change in the independent variables.

\section{Estimation method}

In the quest for the correct exports and imports models, we use the Ordinary Least Squares (OLS) method. The OLS method is suitable for series that are stationary, while its use for non-stationary (trended) series may give spurious results. Intuitively, the explanation is that, when we work with non-stationary data, the presence of a trend in both series can make them appear correlated when, in reality, they are not. Therefore, in order to be able to trust the OLS method, we have to make sure that our series are stationary. However, as can be seen from the stationarity tests reported in the Appendix, all our series are integrated with an order of 1, i.e. are non-stationary.

The natural choice when working with non-stationary data is to use a cointegration technique. Cointegration techniques investigate whether a cointegration exists between non-stationary series, i.e. whether two trended series are moving together over time. For instance, if consumption and income are cointegrated, this means that some equilibrium long-run relationship exists between them. It should be noted that cointegration implies a long-run relationship between the series (for example, over a period of at least twenty years) which means that, in the short-run, the series might not move together. This has two further implications. First, the dynamics of a series is determined both by its long-run relationship with other factors as well as by its short-time relationship with some possibly different factors, i.e. the factors that drive consumption in the long-run may differ from the factors that drive it in the short-run. Nevertheless, the series will, 
in the long-run, tend towards their equilibrium relationship, i.e. every short-run departure from the equilibrium state is short-lived and will soon be corrected. This will be done by an error correction mechanism which is one of the factors that drive consumption in the short-run. ${ }^{3}$ The second implication, particularly important in our case, is that the existence of cointegration assumes a sufficiently long time span. Therefore, even though it would be natural to use a cointegration technique in our case due to nonstationary series, the short time span of twelve years makes the use of cointegration problematic.

Thus, neither the traditional OLS method nor cointegration techniques is completely appropriate. What is commonly done in cases like this is to use them both and to compare the results - if they do not differ greatly, we could consider them to form a true relationship. This is what we have done. We use two alternative cointegration methods the Johansen VECM technique; and the ARDL method. The Johansen vector error correction method (VECM) is very commonly used nowadays and is based on a vector auto regression analysis which treats all variables as both dependent and explanatory; thus, it reduces simultaneity issues (Johansen, 1988, 1991, 1992). Unfortunately, it is a long-sample technique, i.e. it requires a long sample in order to produce reliable results. The auto regressive distributed lag method (ARDL) is based on the OLS method, albeit that it adds dynamics and also separates long-run from short-run relationships. It is believed to have strong short-sample properties (Pesaran and Pesaran, 1997; Pesaran and Shin, 1997; Pesaran et al. 2001).

So, we have based our analysis of export and import determinants on the OLS method, mostly because of clarity and simplicity but also due to our personal belief that, with short samples, OLS is to be preferred to more sophisticated cointegration techniques. We see later on that the OLS and the cointegration results do not differ at all.

\section{Exports}

We began our exports equation modelling in the conventional manner - we estimated a regression with only the real effective exchange rate (REER) and foreign demand as explanatory variables. A priori, we would expect a positive sign on demand and a negative one on the REER (since appreciation would decrease exports). This is exactly what we obtain (see Table 2, column 1) - there is a positive, high and significant coefficient in relation to foreign demand (2.5); and a negative and borderline significant coefficient in relation to the exchange rate $(-0.76)$. If we could accept these results, they would support the thesis that Macedonian exports are exogenously determined, i.e. that export growth is due to favourable demand conditions and that the exchange rate plays little, if any, role.

However, we cannot accept them since the residuals of the regression are clearly not satisfactory (the plots of the residuals of all the regressions are provided in the Appendix), and neither is the fit (72\%). In an attempt to improve the specification, we

3 Furthermore, as the Granger representation theorem states, the relationship between the series can be expressed in an error correction form. This shows how the series evolve in the short-run and is the standard way of expressing cointegrating relationships. 
next added some variables. The first variable we include is metals prices. The inspiration for including this variable comes from the observation that metals exports have experienced rapid growth since 2004. By way of illustration, $76 \%$ of the growth in exports in 2008 came from metals, while metals accounted for $40 \%$ of exports in 2008 and $30 \%$ in 2007. Arguably, what has caused this expansion is not increased world demand for metals but their increased domestic production due to high metals prices. The main reason for the rapid growth in metals prices is, no doubt, increased world demand (although, according to the commodity bubble hypothesis, increased world liquidity and speculation might also have played a role), but if world supply increased enough to meet this increased demand and prices did not change that much, exports would not grow so far.

One caveat with the inclusion of metals prices is that they might also incorporate some other effects: they might capture some aspects of foreign demand - but, arguably, the increase in the world demand for metals is not well captured by our demand variable, which constitutes solely of European countries whereas the demand for metals has been generated by other countries, e.g. People's Republic of China. Furthermore, we should recall that our exports variable is expressed not in real terms but in nominal ones. Thus, rising metals prices will affect exports not just through the increase in the volume of exports, but also through higher export prices. Consequently, it would be impossible to disentangle the price and volume effects of metals prices, although this is not a major concern in our case.

The results change dramatically with this specification (see Table 2, column 2). The demand coefficient drops by nearly one-half (1.4), suggesting both that some of the effect of foreign demand might now be captured by metals prices, as well as that some of the effect of metals prices might previously have been captured by foreign demand. Metals prices appear with a fairly high coefficient (0.33), indicating that they have a high export elasticity. Both coefficients are significant at the $1 \%$ level. However, the exchange rate is now not only insignificant - but with the wrong sign, too. The fit of the regression is substantially improved ( $86 \%)$, indicating a higher explanatory power. The residuals, however, fail to improve - so we may dismiss this specification and move on.

The poor residuals of the two specifications should not surprise us, since it has been acknowledged in the literature that the export performance of small countries depends to a large extent on how much they can produce, i.e. on their production capacity, since, facing a given level of demand for their exports, they can sell almost anything they can produce. Consequently, we continue our pursuit for the right specification by including a variable for production capacity - industrial production. By itself, industrial production might not be the best proxy for production capacity, since it depends to a great extent on capacity utilisation. However, capacity utilisation in Macedonia is fairly stable (at around $63 \%{ }^{4}$ ) and this gives credence to the use of industrial production for this purpose.

4 The data on capacity utilisation, from the Survey of Business Trends in Manufacturing Industry, published by the State Statistical Office, is available only since 2003. This precludes a calculation of production capacity as industrial production divided by capacity utilisation. 
Here, we arrive at a satisfactory specification (Table 2, column 3) since, for the first time, we obtain satisfactory residuals. ${ }^{5}$ The fit also improves, to $94 \%$. Concerning the coefficients, the foreign demand coefficient restores some of its magnitude (2.1), indicating a fairly high income elasticity of exports. The metals prices coefficient drops by more than one-half $(0.13)$, suggesting that the high coefficient of the previous specification has been spurious and that metals prices do affect exports. Industrial production appears with a relatively high coefficient (1.4), indicating that export expansion has occurred partly as a result of increased domestic production. All these variables are highly significant. In contrast, the exchange rate is insignificant - once more implying that exports have indeed not been dependent on the exchange rate. However, the sign is correct.

Despite the good results, some ambiguities remain. First, we can see that the coefficient of foreign demand varies greatly in all three specifications (1.4, 2.1 and 2.5). The high coefficient in the first specification was due to the omission of metals prices, while the low coefficient in the second was due to metals reflecting some effect of demand, but it would be interesting to see how robust these findings are. Second, metals prices are also likely to be highly correlated with production capacity - higher prices induce higher investment and thus metals prices can incorporate some of the effects of industrial production.

To explore these two issues, we can see what happens with the regression results when we exclude metals prices (Table 2, column 4). We may observe that the coefficient of industrial production changes slightly (from 1.4 to 1.8), as does the demand coefficient (from 2.1 to 2.6). At the same time, the regression fit changes only marginally (from $94 \%$ to $93 \%$ ). The small change in the explanatory power would suggest that metals prices exert only a small effect in addition to the previously included variables and that the small change in the industrial production and foreign demand coefficients should be interpreted as evidence that metals prices might, at worst, capture only a small part of their effect.

5 The serial correlation test is borderline significant (the null of no serial correlation can be rejected at the $1 \%$ level of significance, but not at the $5 \%$ ), so we opt for the lower level. 
Table 2 - Results of the OLS models for exports

\begin{tabular}{|c|c|c|c|c|c|c|c|}
\hline & $-1-$ & $-2-$ & $-3-$ & $-4-$ & $\begin{array}{c}-5- \\
\text { no first } 4 \\
\text { lags }\end{array}$ & $\begin{array}{c}-6- \\
\text { no last } 4 \\
\text { lags }\end{array}$ & $\begin{array}{c}-7- \\
\text { no first } \\
\text { and last } 4 \\
\text { lags }\end{array}$ \\
\hline $\log$ _fordem & $2.498 * * *$ & $1.416^{* * *}$ & $2.145 * * *$ & $2.611 * * *$ & $2.665 * * *$ & $2.078 * * *$ & $2.569 * * *$ \\
\hline & $(0.000)$ & $(0.000)$ & $(0.000)$ & $(0.000)$ & $(0.000)$ & $(0.000)$ & $(0.000)$ \\
\hline log_reer & $-0.762 *$ & 0.284 & -0.156 & $-0.539 * *$ & -0.132 & -0.151 & 0.154 \\
\hline & $(0.082)$ & $(0.426)$ & $(0.528)$ & $(0.024)$ & $(0.671)$ & $(0.560)$ & $(0.643)$ \\
\hline log_metals & & $0.329 * * *$ & $0.134 * * *$ & & $0.111^{* *}$ & $0.134 * * *$ & $0.120 * * *$ \\
\hline & & $(0.000)$ & $(0.004)$ & & (0.099) & $(0.006)$ & $(0.101)$ \\
\hline log_ind & & & $1.402 * * *$ & $1.759 * * *$ & $1.464 * * *$ & $1.317 * * *$ & $1.387 * * *$ \\
\hline & & & $(0.000)$ & $(0.004)$ & $(0.000)$ & $(0.000)$ & $(0.000)$ \\
\hline Constant & 1.902 & 1.986 & $\begin{array}{c}-7.333 \\
* * *\end{array}$ & $\begin{array}{l}-9.727 \\
* * *\end{array}$ & $\begin{array}{c}-11.429 \\
* * *\end{array}$ & $-6.562 * *$ & -10.645 \\
\hline & $(0.606)$ & $(0.461)$ & $(0.002)$ & $(0.000)$ & $(0.000)$ & $(0.011)$ & $(0.003)$ \\
\hline $\begin{array}{l}\text { LM serial } \\
\text { correlation } \\
\text { test }\end{array}$ & 0.000 & 0.000 & 0.045 & 0.030 & 0.022 & 0.033 & 0.016 \\
\hline $\begin{array}{l}\text { Jarque-Bera } \\
\text { normality test }\end{array}$ & 0.231 & 0.632 & 0.424 & 0.463 & 0.458 & 0.443 & 0.576 \\
\hline $\begin{array}{l}\text { Koenker- } \\
\text { Bassett } \\
\text { heteroskedast } \\
\text { icity test }\end{array}$ & 0.149 & 0.282 & 0.198 & 0.238 & 0.191 & 0.545 & 0.508 \\
\hline Observations & 47 & 47 & 47 & 47 & 43 & 43 & 39 \\
\hline R-squared & 0.724 & 0.856 & 0.936 & 0.932 & 0.949 & 0.915 & 0.916 \\
\hline
\end{tabular}

$* * * p<0.01, * * p<0.05, * p<0.1$

$p$ values in parentheses 


\section{Imports}

The initial specification of the imports equation explains imports as a function of domestic GDP and the real effective exchange rate. We obtain (Table 3, column 1) a high and significant GDP coefficient (3.1) as well as a wrongly signed, low and insignificant exchange rate coefficient $(-0.2$; we would have expected a positive coefficient, since exchange rate appreciation should stimulate imports). If we could accept this specification, it would tell us that imports are driven solely by GDP, with a very high level of response, and that the exchange rate does not affect them. The fit of the regression is good $(93 \%)$, but we may dismiss these results as a result of the unsatisfactory residuals.

We looked to improve the initial model in a manner similar to that undertaken by Petreski and Jovanovic (2009). Namely, instead of investigating how aggregate domestic activity affects imports, we inspect how the separate components of GDP affect it. Thus, we start by substituting our previous income variable, GDP, with private consumption, the rationale for doing so being that the major part of imports consists of goods that are consumed in Macedonia. However, the results of this model (Table 3, column 2) seem even worse - the residuals fail to improve and the fit lowers to $90 \%$, so we need to keep looking.

A large part of Macedonian imports consists of intermediary goods, i.e. goods which are processed and then exported, so we added exports to our specification. The results improve significantly - the residuals now seem not to suffer from serial correlation, non-normality and heteroskedasticity, while the fit jumps to $96 \%$ (Table 3, column 3 ). The coefficient of consumption drops to 0.7 , suggesting a moderate response of imports to consumption growth, while exports attract a coefficient of 0.6. The exchange rate appears with an insignificant, as well as low (0.1), coefficient.

Finally, we added gross investment to this specification in order to see whether the increase in imports can be explained by intensified investment activity (Table 3, column 4). The residuals again seem fine while all the coefficients, including the exchange rate, are significant and with the expected signs. Gross investment has a coefficient of 0.25 , implying that some part of imports is due to investment activity, especially in the last four quarters, as evidenced by the significantly lower residuals for this period in the specification with investment. The inclusion of investment lowers all the other coefficients, but only slightly. The exchange rate attracts a significant, and correctly signed, coefficient of 0.33 , implying that imports do react to exchange rate changes, but only slightly. The fit improves further, reaching $98 \%$.

Before we conclude the imports equation, we explore one more issue. Similarly to exports, imports might also be affected by oil and metals prices since imports are in nominal terms and oil and metals constitute a major part of these. Thus, we investigate whether the inclusion of oil and metals prices changes the results in any way (Table 3, columns 5 and 6). The coefficients for both oil and metals prices appear insignificant, while no other coefficient changes significantly. This is not such a strange result - all the variables in this imports equation are in nominal terms, so the effect of the oil and metals prices has already been incorporated. For comparison, the foreign demand variable in the exports equation was in real terms. 
Table 3 - Results of the OLS models for imports

\begin{tabular}{|c|c|c|c|c|c|c|c|c|c|}
\hline & $-1-$ & $-2-$ & $-3-$ & $-4-$ & $-5-$ & $-6-$ & $\begin{array}{c}-7- \\
\text { no } \\
\text { first } 4 \\
\text { lags }\end{array}$ & $\begin{array}{c}-8- \\
\text { no last } \\
4 \text { lags }\end{array}$ & $\begin{array}{c}-9- \\
\text { no } \\
\text { first } \\
\text { and } \\
\text { last } 4 \\
\text { lags }\end{array}$ \\
\hline \multirow[t]{2}{*}{$\log$ gdp } & $\begin{array}{c}3.081 \\
* * *\end{array}$ & & & & & & & & \\
\hline & 0.000 & & & & & & & & \\
\hline \multirow[t]{2}{*}{ log_reer } & -0.220 & -0.086 & 0.118 & $\begin{array}{c}0.335 \\
* *\end{array}$ & $\begin{array}{c}0.368 \\
* *\end{array}$ & 0.210 & $\begin{array}{c}0.675 \\
* * *\end{array}$ & $\begin{array}{c}0.334 \\
* *\end{array}$ & $\begin{array}{c}0.677 \\
* * *\end{array}$ \\
\hline & 0.341 & 0.719 & 0.447 & 0.021 & 0.013 & 0.190 & 0.000 & 0.028 & 0.001 \\
\hline \multirow[t]{2}{*}{$\log$ _cons } & & $\begin{array}{c}1.220 \\
* * *\end{array}$ & $\begin{array}{c}0.656 \\
* * *\end{array}$ & $\begin{array}{c}0.566 \\
* * *\end{array}$ & $\begin{array}{c}0.687 \\
* * *\end{array}$ & $\begin{array}{c}0.596 \\
* * *\end{array}$ & $\begin{array}{c}0.811 \\
* * *\end{array}$ & $\begin{array}{c}0.565 \\
* * *\end{array}$ & $\begin{array}{c}0.804 \\
* * *\end{array}$ \\
\hline & & 0.000 & 0.000 & 0.000 & 0.000 & 0.000 & 0.000 & 0.000 & 0.000 \\
\hline \multirow[t]{2}{*}{ log_expo } & & & $\begin{array}{c}0.583 \\
* * *\end{array}$ & $\begin{array}{c}0.437 \\
* * *\end{array}$ & $\begin{array}{c}0.463 \\
* * *\end{array}$ & $\begin{array}{c}0.534 \\
* * *\end{array}$ & $\begin{array}{c}0.368 \\
* * *\end{array}$ & $\begin{array}{c}0.436 \\
* * *\end{array}$ & $\begin{array}{c}0.372 \\
* * *\end{array}$ \\
\hline & & & 0.000 & 0.000 & 0.000 & 0.000 & 0.000 & 0.000 & 0.000 \\
\hline \multirow[t]{2}{*}{ log_inv } & & & & $\begin{array}{c}0.251 \\
* * *\end{array}$ & $\begin{array}{c}0.248 \\
* * *\end{array}$ & $\begin{array}{c}0.243 \\
* * *\end{array}$ & $\begin{array}{c}0.233 \\
* * *\end{array}$ & $\begin{array}{c}0.243 \\
* * *\end{array}$ & $\begin{array}{c}0.234 \\
* * *\end{array}$ \\
\hline & & & & 0.000 & 0.000 & 0.000 & 0.000 & 0.000 & 0.000 \\
\hline \multirow[t]{2}{*}{ log_oil } & & & & & -0.053 & & & & \\
\hline & & & & & 0.251 & & & & \\
\hline \multirow[t]{2}{*}{ log_metals } & & & & & & -0.089 & & & \\
\hline & & & & & & 0.118 & & & \\
\hline & & & & & & & & & \\
\hline
\end{tabular}




\begin{tabular}{|c|c|c|c|c|c|c|c|c|c|}
\hline & $-1-$ & $-2-$ & $-3-$ & $-4-$ & $-5-$ & $-6-$ & $\begin{array}{c}-7- \\
\text { no } \\
\text { first } 4 \\
\text { lags }\end{array}$ & $\begin{array}{c}-8- \\
\text { no last } \\
4 \text { lags }\end{array}$ & $\begin{array}{c}-9- \\
\text { no } \\
\text { first } \\
\text { and } \\
\text { last } 4 \\
\text { lags }\end{array}$ \\
\hline Constant & $\begin{array}{l}-22.05 \\
* * *\end{array}$ & -2.281 & $\begin{array}{c}-2.985 \\
* *\end{array}$ & $\begin{array}{c}-3.935 \\
* * *\end{array}$ & $\begin{array}{c}-5.434 \\
* * *\end{array}$ & $\begin{array}{l}-4.198 \\
* * *\end{array}$ & $\begin{array}{c}-7.284 \\
* * *\end{array}$ & $\begin{array}{c}-3.834 \\
* * *\end{array}$ & $\begin{array}{c}-7.267 \\
* * *\end{array}$ \\
\hline & 0.000 & 0.240 & 0.019 & 0.001 & 0.002 & 0.000 & 0.000 & 0.002 & 0.000 \\
\hline $\begin{array}{l}\text { LM serial } \\
\text { correlation } \\
\text { test }\end{array}$ & 0.005 & 0.001 & 0.136 & 0.178 & 0.309 & 0.238 & 0.859 & 0.184 & 0.873 \\
\hline $\begin{array}{l}\text { Jarque-Bera } \\
\text { normality test }\end{array}$ & 0.926 & 0.398 & 0.448 & 0.377 & 0.718 & 0.143 & 0.632 & 0.362 & 0.657 \\
\hline $\begin{array}{l}\text { Koenker- } \\
\text { Bassett test for } \\
\text { hetero- } \\
\text { skedasticity }\end{array}$ & 0.234 & 0.927 & 0.551 & 0.346 & 0.157 & 0.829 & 0.726 & 0.619 & 0.638 \\
\hline Observations & 47 & 51 & 51 & 43 & 43 & 43 & 39 & 39 & 35 \\
\hline $\mathrm{R}$-squared & 0.925 & 0.917 & 0.967 & 0.983 & 0.983 & 0.984 & 0.986 & 0.968 & 0.973 \\
\hline
\end{tabular}

$* * * p<0.01, * * p<0.05, * p<0.1$

$p$ values in parentheses

Consequently, our analysis confirms the findings of Petreski and Jovanovic (2009) as to what, in our opinion, constitutes an appropriate way of modelling Macedonian imports - i.e. as a function of separate GDP components. This shows that imports are elastic as regards the growth in consumption - but that exports, as well as investments, contribute considerably to the growth in imports. The low and significant exchange rate coefficient indicates that imports do depend on the real exchange rate, but that major changes in the exchange rate are required in order to affect imports. We consider this finding plausible, given the small size of the Macedonian economy and the high level of dependence on imports.

\section{Further investigation}

In order to examine whether the relationships just described really do hold, we investigate their robustness. We start by investigating whether the sample selection affects the results, i.e. whether our findings are affected by changes in the sample. First we exclude the first four quarters, then we exclude the last four quarters and, finally, we exclude them both (see the last three columns of Tables 2 and 3). It is obvious that some of the coefficients change a little, but nothing changes dramatically. 
We also inspect the stability of the parameters (see Appendix). For this purpose, we use the CUSUM test, the CUSUM squares test, the Chow breakpoint test and the Chow forecasting test (for the latter two, we have set the breakpoint date at the middle of the sample-Q4 2002). Some evidence exists for parameter instability (under the Chow breakpoint test), but the overwhelming evidence favours the thesis that there is no structural break in the exports and imports regressions.

We next turn to the robustness of the results as regards the estimation method, i.e. we investigate whether the Johansen and the ARDL methods give different results for our final exports and imports models. To conserve space here, we explain neither the whole process nor the details. ${ }^{6}$ However, with the Johansen technique, we set the order of the VAR to 1 for both the models, since this was suggested by all the information criteria. We then tested for cointegration and determined the presence of deterministic components according to the Pantula principle. In both cases, we have 1 cointegrating vector; option 3 for exports (constant in the long-run equation and no trends); option 2 for imports (constant in the short-run equation and no trends); while the decision was not clear-cut for exports. Finally, we can obtain the cointegrating relationship.

As for the ARDL method, we set the maximum number of lags in the ARDL to 1, due to the good residuals with 1 lag, and because we do not expect higher inertia. We then tested for cointegration; the test results were not unanimous but we proceed here as if we had cointegration.

The results obtained with the cointegration methods are presented in Table 4, for exports; and Table 5, for imports (the acronyms adjacent to the ARDL refer to the criterion on which the choice of the lags has been made). The similarity of the coefficients is striking. The only major difference within the Johansen specification for exports is the higher foreign demand and the lower industrial production coefficient; the coefficient for REER is insignificant everywhere. The imports coefficients are even more similar. Another aspect worth mentioning is the relatively high ECM coefficients, which imply a very high restoration of the equilibrium at levels lower than six months. This might seem too quick, but it actually tells us that no major deviations from the equilibrium position exist in the exports and imports relationships. Thus, our cointegration results confirm our previous findings.

6 For an explanation of the process, refer to Jovanovic (2007), for example; or see Harris and Sollis (2003) and Pesaran and Pesaran (1997). The details of the procedure are available upon request. 
Table 4 - Comparison between the OLS, Johansen and ARDL results for exports

\begin{tabular}{|l|c|c|c|c|}
\hline & OLS & Johansen & ARDL (SBC) & ARDL (R-sq) \\
\hline log_fordems & 2.145 & 3.131 & 2.116 & 2.286 \\
\hline & $(8.317)$ & $(8.842)$ & $(4.901)$ & $(5.483)$ \\
\hline $\log$ reer & & & & \\
\hline & -0.156 & -0.196 & -0.081 & -0.256 \\
\hline & $(0.636)$ & $(0.587)$ & $(0.188)$ & $(0.616)$ \\
\hline $\log$ metals & & & & 0.135 \\
\hline & 0.134 & 0.125 & $(2.110)$ & $(1.656)$ \\
\hline & $(3.050)$ & $(2.087)$ & & $(175$ \\
\hline $\log$ ind & 1.402 & 0.793 & 1.589 & 1.729 \\
\hline & $(7.266)$ & $(2.895)$ & $(4.958)$ & $(5.301)$ \\
\hline & & & & $(2.582)$ \\
\hline Constant & -7.333 & -8.242 & -8.610 & -9.412 \\
\hline & $(3.319)$ & & -0.503 & -0.529 \\
\hline & & -0.282 & $(5.769)$ & $(4.422)$ \\
\hline ECM & & & & \\
\hline & & & & \\
\hline
\end{tabular}

Absolute value of the t statistics in parentheses; value higher than 2 indicates significance 
Table 5 - Comparison between the OLS, Johansen and ARDL results for imports

\begin{tabular}{|c|c|c|c|c|}
\hline & OLS & Johansen & $\begin{array}{l}\text { ARDL } \\
\text { (SBC) }\end{array}$ & $\begin{array}{l}\text { ARDL } \\
\text { (R-sq) }\end{array}$ \\
\hline \multirow[t]{2}{*}{ log_reer } & 0.335 & 0.350 & 0.455 & 0.433 \\
\hline & (3.619) & (2.693) & (3.878) & (2.900) \\
\hline \multirow[t]{2}{*}{ log_cons } & 0.566 & 0.611 & 0.663 & 0.671 \\
\hline & $(2.412)$ & $(8.650)$ & $(9.460)$ & (7.377) \\
\hline \multirow[t]{2}{*}{ log_expo } & 0.437 & 0.445 & 0.416 & 0.398 \\
\hline & (7.534) & (8.867) & (9.973) & $(7.230)$ \\
\hline \multirow[t]{2}{*}{ log_inv } & 0.251 & 0.189 & 0.223 & 0.219 \\
\hline & $(8.150)$ & $(5.282)$ & $(8.240)$ & $(5.071)$ \\
\hline \multirow[t]{2}{*}{ Constant } & -3.935 & -4.008 & -5.083 & -4.837 \\
\hline & $(6.905)$ & (3.938) & (5.140) & (3.819) \\
\hline \multirow[t]{2}{*}{ ECM } & & -0.563 & -1 & -0.800 \\
\hline & & (1.622) & NA & $(6.085)$ \\
\hline
\end{tabular}

Absolute value of the t statistics in parentheses; value higher than 2 indicates significance

\section{Discussion}

The story of Macedonian exports and imports would perhaps best be illustrated by showing the relative merit of the individual factors in the dynamics of exports and imports. $^{7}$ This is conveyed in Figure 1 and Figure 2. The dashed lines show the total

7 We calculate these approximate contributions by the following formula, where 'contr' stands for the contribution of the variable to total growth; 'coef' for the respective coefficient; ' $\Delta$ var' for the change in the respective variable (in logs); ' $\Delta$ total' for the total annual growth in exports or imports; and ' $\mathrm{j}$ ' is the total number of independent variables:

$$
\text { Contr }_{i}=\frac{\operatorname{Coef}_{i}^{* \Delta \text { Var }_{i}}}{\sum_{i=1}^{j}\left(\operatorname{Coef}_{i} * \Delta \text { Var }_{i}\right)} * \Delta \text { Total }
$$


annual growth, in percentages, while the bars show how much of this total growth is due to the individual factors.

Figure 1 - Contribution of the individual determinants to the annual growth rates of exports

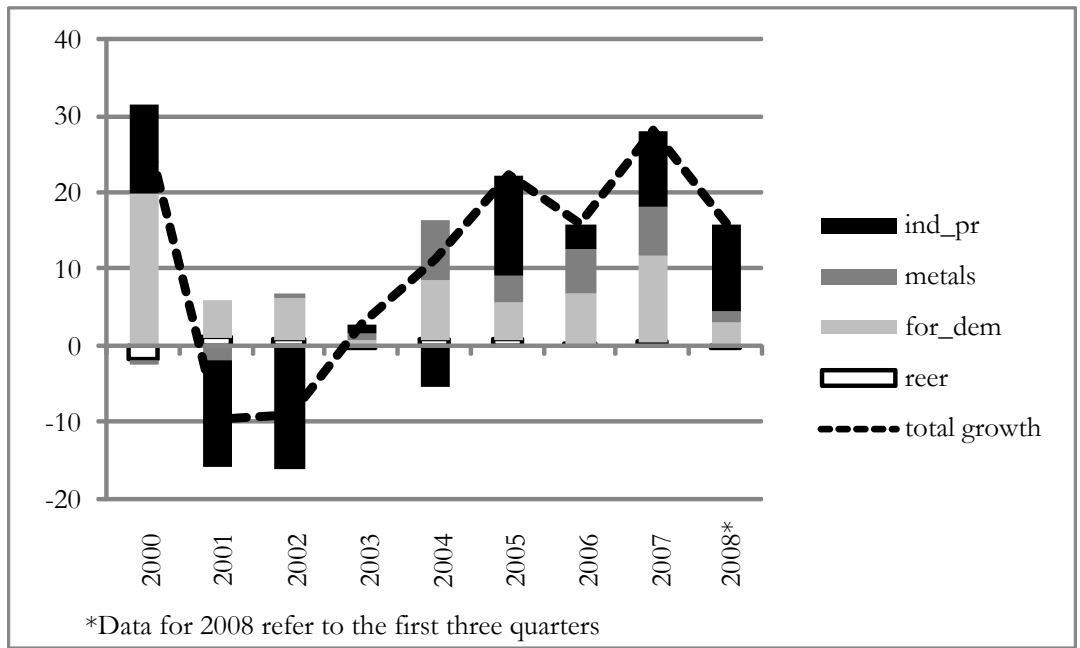

Figure 2-Contribution of the individual determinants to the annual growth rates of imports

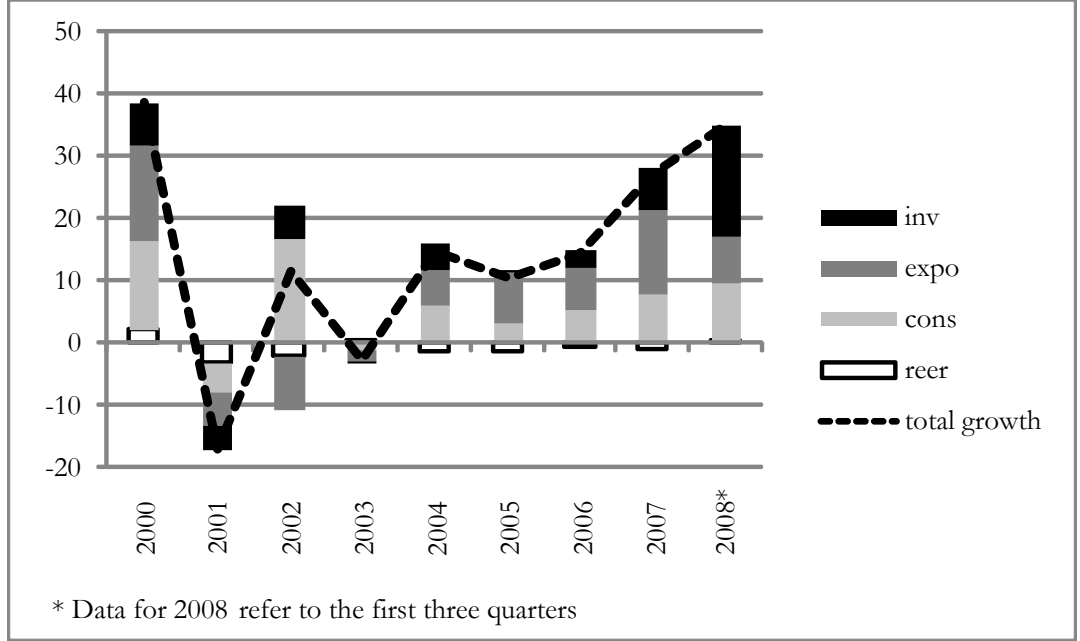

As for exports, there are a few things which are worth noting. The total export dynamic has been driven to a large extent by industrial production. The fall in exports 
in 2001 and 2002 was almost completely due to the fall in production (in 2001, there was internal conflict in Macedonia); while industrial production has also contributed substantially to the rise over the last three years. After being almost irrelevant to the export dynamic prior to 2004, metals prices thereafter became a very important factor in the growth of exports during the following five years. At the same time, foreign demand contributed positively to export growth throughout the whole period. So, export expansion since 2005 has been a consequence of favourable external demand, accompanied by high metals prices and increased domestic production.

Regarding the exchange rate - throughout the whole period, its contribution to the total growth in exports was not much more than zero.

On the imports side, consumption appears to be the most stable contributor, making a positive contribution in each year except for two (including 2001, the year of the conflict). This is not at all surprising, bearing in mind limited domestic production capacities. However, the factor that has made imports grow considerably in the last five years is not consumption, but exports. As may be observed, in the last five years the contribution of exports regularly exceeded that of consumption. Even so, there is one additional factor, often overlooked, which has made imports leap in the last couple of years - intensified investment activity. Across the whole period, the contribution of the exchange rate, although slightly higher than in the case of exports, is always only marginal.

Thinking about these findings, it is not particularly strange that imports depend only marginally on the exchange rate - this is often the case for small open economies, lacking in natural resources, which must import everything that they cannot produce themselves. Furthermore, some previous studies for Macedonia have indicated that imports are not particularly price elastic (Jovanovic, 2007; Petreski and Jovanovic, 2009). However, it does seem strange to claim that exports are totally inelastic with respect to the exchange rate, since up to now, in accordance with prior research, it has always been believed that the opposite is the case - i.e. that exports depend to a large extent on the exchange rate.

A few points are worth emphasising here. The first is that we are not claiming that exports do not depend on the exchange rate at all, or that they will not in the future. We do, however, claim that export dynamics in the period under analysis was not determined by the exchange rate but by other factors. This seems quite reasonable. Exports grew considerably in this period (in 2008, they were nearly three times higher than in 1997), and especially after 2004 (in 2008, they were double what they were in 2004). This most recent expansion was due, first and foremost, as we have explained, to the increased export of metals. Thus, if we are thinking of the factors that caused exports to grow this substantially, we must think about what caused metals exports to grow. One of the most important factors here is metal prices. On the other hand, the exchange rate of the denar is unlikely to affect exports of metals - the price of metals is expressed in dollars, so the exchange rate of the denar does not affect it.

This helps to explain why some previous studies have found that the exchange rate influences exports. To be sure, the data and the variables can affect the results to a major extent. For example, the real effective exchange rate from IFS Statistics and the NBRM differ substantially. Additionally, the difference in the results obtained from 
various empirical research studies could be a consequence of the problem of omitted variables. If we look at export regressions without metals prices (Table 2, columns 2 and 4), we can see that the coefficient of the exchange rate was significant (at the $10 \%$ level in the former case; at the $5 \%$ level in the latter). However, taking metals prices into account renders the exchange rate coefficient insignificant. This is because metals prices and the real exchange rate move in the opposite direction - and very closely, it would seem (see Figure A1 in the Appendix). Thus, omitting metals prices from the exports equation can indicate, wrongly, that the exchange rate is a significant determinant of export dynamics.

However, Macedonian exports do not consist only of metals. What about the rest of exports? It would be hard to say that these do not depend at all on the exchange rate. The point is that these other products would have to be very elastic to changes in exchange rates in order for total exports also to appear elastic. If one-third of exports is completely inelastic (metals) and one-third is unitary elastic, the remaining one-third would need to have an elasticity of 3.5 in order for total exports to have an elasticity of $1.5 .^{8}$ It is difficult to anticipate such a high level of elasticity: usually, services are considered to be that elastic - restaurants, travel, tourism and maybe some luxury goods (see Houthakker and Taylor, 1970), but Macedonia exports none of these. Thus, even were some part of exports to be elastic, then the result of the dominance of inelastic metals is that total exports might appear inelastic, too.

The reader might get the feeling that our analysis of the determinants of trade has been biased towards exports in terms of the space dedicated to them. This is quite true, and is due to the existing literature on Macedonian trade quite simply being almost unanimously geared towards showing that exports are highly price elastic; in contrast, the findings for imports are less clear-cut. However, one must not neglect that, in reality, devaluation is often used as a measure to destimulate imports, not to stimulate exports. Thinking about this thesis, our analysis has definitely shown that Macedonian imports do depend on the exchange rate and that devaluation is likely to have an impact on imports. The important question here is one of how big that impact might be. We will leave this question aside, since any precise assessment needs an analysis of a different

8 Elasticity is the ratio of two percentage changes. Assume that the initial state of exports was 100 and the structure of exports is: inelastic goods $=50$; unitary elastic $=25$; highly elastic $=25$. The corresponding changes in total exports, the inelastic part and the moderately elastic part, arising from a $1 \%$ change in the exchange rate are as calculated in the table below. The change in the highly elastic part is calculated as the difference between these, while the corresponding elasticity reflects the percentage change in the final compared to the initial state.

\begin{tabular}{llll}
\hline & $\begin{array}{l}\text { Initial } \\
(\mathbf{A})\end{array}$ & $\begin{array}{l}\text { Elasticity } \\
(\mathbf{B})\end{array}$ & $\begin{array}{l}\text { Final } \\
\left(\mathbf{A}^{*}(\mathbf{1 + B} \mathbf{- 1 0 0})\right)\end{array}$ \\
\hline Total exports & 100 & 1.5 & 101.5 \\
Inelastic part & 34 & 0 & 34 \\
Moderately elastic & 33 & 1 & 33.33 \\
Highly elastic & 33 & $3.5=(34.17 / 33-1) * 100$ & $34.17=101.5-34-33.33$ \\
\hline
\end{tabular}


type, but, by looking at exchange rate elasticity and exchange rate pass-through from the studies previously mentioned, we can definitely say that the effect will be very small. Just for illustration, if a $10 \%$ nominal depreciation results in a $6 \%$ real depreciation (since the exchange rate pass-through is around 0.4 ) then, given the exchange rate elasticity of imports of 0.35 , this is likely to result in a decline in imports of around $2 \%$.

On the other hand, the recent expansion of imports was mainly due to intensified investment activity, accompanied by the expansion of exports, so, given the likely downward prospects for exports and investment, we can be quite certain that imports will fall, too. This fall will almost definitely exceed the fall that will be brought by a possible devaluation.

In terms of net exports, thus, as our analysis has shown, devaluation is not likely to have any major effect. However, there might be other factors that support devaluation among them, for instance, the depreciation of other currencies. Almost all central and eastern European countries with flexible exchange rate regimes have experienced depreciations in the last few months, with possibly even higher depreciations ahead. These countries represent major trading partners for Macedonia, so this implies a possible further worsening of the trade balance for Macedonia.

When thinking about this question, as well as about many others, one should always remember that the issue of the right parity of a currency is best analysed using the apparatus of some equilibrium exchange rate concept, like the Fundamental Equilibrium Exchange Rate. Put simply, one should analyse the real effective exchange rate vis-à-vis the equilibrium real exchange rate, and devaluation should only be considered if the currency is overvalued. Following this logic, the depreciation of the currencies of trading partners implies a real appreciation of the Macedonian denar. If, at the same time, the equilibrium real exchange rate does not appreciate, the real exchange rate might become overvalued. This might be considered as a valid argument for devaluation. However, this is a topic for another article.

\section{Conclusion}

The issue of the determinants of exports and imports has received significant attention in the literature as a result of the special place that trade has always had in the economic literature. This issue is even more important for small, open economies, whose performance depends critically on trade. In the case of Macedonia, the situation is even more pronounced since it has been always considered that the exchange rate is an important policy instrument and that changes in the exchange rate can, to a great extent, influence other aspects of performance. The episode of the devaluation of the denar in 1997 clearly illustrates this stance.

The recent good performances in the external sector, and in the economy generally, have contributed greatly to economists in Macedonia stopping thinking about the exchange rate, at least for a while. However, the usual tendency - in difficult times, when no viable solution is known, to come up with recommendations that are drastic - is confirmed yet again in Macedonia. The recent deterioration in external performances, due to the global financial and economic crisis, have made economists claim that the economy can be made better off by devaluing the currency. 
We argue that this is not likely to be the case. In order for the nominal exchange rate, which is under the direct control of the policy-makers, to have a real effect on trade, two conditions must be met - it first has to be able to affect the real exchange rate; and then the real exchange rate would have to be able to affect trade flows. Regarding the first condition, previous studies have shown that a given change in the nominal exchange rate is likely to result in a smaller change in the real exchange rate, due to the high exchange rate pass-through. Regarding the second condition, we show here that external sector performances have not in the past been determined by the real exchange rate and, therefore, are unlikely in the future to depend on it either.

However, even if the exchange rate is unlikely to be the factor that is responsible for the poor performance of net exports, the case for devaluation can be strong. In fact, rarely is devaluation used as a measure to stimulate net exports; more often, it is used as a measure to restore equilibrium more quickly. This means that what is important concerning devaluation is whether, and how much, the actual exchange rate differs from the equilibrium. Therefore, in order to argue against devaluation more soundly, one should consider some equilibrium real exchange rate concept - for instance, the Fundamental Equilibrium Exchange Rate. This marks the path for future research.

Nevertheless, besides speaking out loudly against devaluation, this research study would like to point to another issue - that the public in Macedonia, including journalists, economists and policy-makers, should start making their arguments on solid grounds. It is about time. If this is achieved, this article could be considered to have been successful.

\section{References}

Athukorala, P and J. Riedel (1994) 'Demand and Supply Factors in the Determination of Nie Exports: A Simultaneous Error-Correction Model for Hong Kong: A Comment' The Economic Journal 104(427) (November): 1411-1414.

Besimi, F, G. Pugh and N. Adnett (2006) The monetary transmission mechanism in Macedonia: implications for monetary policy Working Paper No. 02/2006, Institute for environment and sustainability research.

Dornbusch, R (1985) 'Policy performance links between LDC debtors and industrial nations' Brookings Papers on Economic Activity Vol. 2, pp. 303-366.

Goldstein, M and M. S. Khan (1978) 'The supply and demand for exports: A simultaneous approach' The Review of Economics and Statistics 60: 275-286.

Goldstein, M and M. S. Khan (1982) Effects of slow-down in industrial countries on growth in non-oil developing countries Occasional Paper No. 12, International Monetary Fund.

Goldstein, M and M. S. Khan (1985) 'Income and Price Effects in Foreign Trade' in R. W. Jones and P. B. Kenen (eds.) Handbook of International Economics Elsevier Science Publishers: Amsterdam.

Harris, R and R. Sollis (2003) Applied Time Series Modelling and Forecasting John Wiley and Sons. 
Holly, S and K. Wade (1991) 'UK exports of manufactures: the role of supply-side factors' Scottish Journal of Political Economy 38: 1-18.

Houthakker, H. S and S. P. Magee (1969) 'Income and Price Elasticities in World Trade' The Review of Economics and Statistics 51(2): 111-125.

Houthakker, H. S and L. D. Taylor (1970) Consumer Demand in the United States, 1929-1970 Harvard University Press: Cambridge.

Johansen, S (1988) 'Statistical Analysis of Cointegration Vectors' Journal of Economic Dynamics and Control 12: 231-254.

Johansen, S (1991) 'Estimation and Hypothesis Testing of Cointegration Vectors in Gaussian Vector Autoregressive Models’ Econometrica 59(6): 1551-1580.

Johansen, S (1992) 'Determination of Cointegration Rank in the Presence of a Linear Trend' Oxford Bulletin of Economics and Statistics 54(3): 383-397.

Jovanovic, B (2007) The Fundamental Equilibrium Exchange Rate of the Denar unpublished Masters thesis, Staffordshire University: UK.

Kadievska-Vojnovic, M and D. Unevska (2007) Price and Income Elasticities of Export and Import and Economic Growth in the Case of the Republic of Macedonia Working Paper, National Bank of the Republic of Macedonia.

Krstevska, A, S. Bojceva-Terzijan, B. Davidovska-Stojanova and F. Besimi (2004) Exchange rate pass-through and the monetary strategy of the National Bank of the Republic of Macedonia Economic Research Paper No. 7/II/2003.

Krugman, P (1989) 'Income elasticities and Real Exchange Rates' European Economic Review 33: 1031-1054.

Muscatelli, V. A (1994) 'Demand and Supply Factors in the Determination of NIE Exports: A Reply’ The Economic Journal 104(427) (November): 1415-1417.

Muscatelli, V. A, T. G. Srinivasan and D. Vines (1990) The empirical modelling of NIE exports: an evaluation of different approaches CEPR discussion paper No. 426.

Muscatelli, V. A, T. G. Srinivasan and D. Vines (1990) 'Demand and Supply Factors in the Determination of NIE Exports: A Simultaneous Error-Correction Model for Hong Kong' The Economic Journal 102(415) (November): 1467-1477.

Pesaran, M. H and B. Pesaran (1997) Working with Microfit 4: Microfit 4 User Manual Oxford University Press.

Pesaran, M. H and Y. Shin (1997) An Autoregressive Distributed Lag Modeling Approach to Cointegration Analysis Cambridge Working Papers in Economics, No. 9514.

Pesaran, M. H, Y. Shin and R. J. Smith (2001) 'Bounds testing approaches to the analysis of level relationships' Journal of Applied Econometrics 16(3): 289-326.

Petreski, M. and B. Jovanovic (2009) 'Keynesian Macroeconomic Model of the Republic of Macedonia: Economic Theory and Behavioural Equations' Ministry of Finance of the Republic of Macedonia Bulletin. 
Riedel, J (1984) 'Trade as the engine of growth in developing countries, revisited' Economic Journal 94: 56-73.

Riedel, J (1988) 'The demand for LDC Exports of Manufactures: Estimates from HongKong’ Economic Journal 98: 138-148.

Vrboska, A (2006) Choice of optimal monetary strategy for small and open economies unpublished Masters thesis, Faculty of Economics, Skopje. 


\section{Appendix}

Figure A1 - Plots of the series used in the analysis
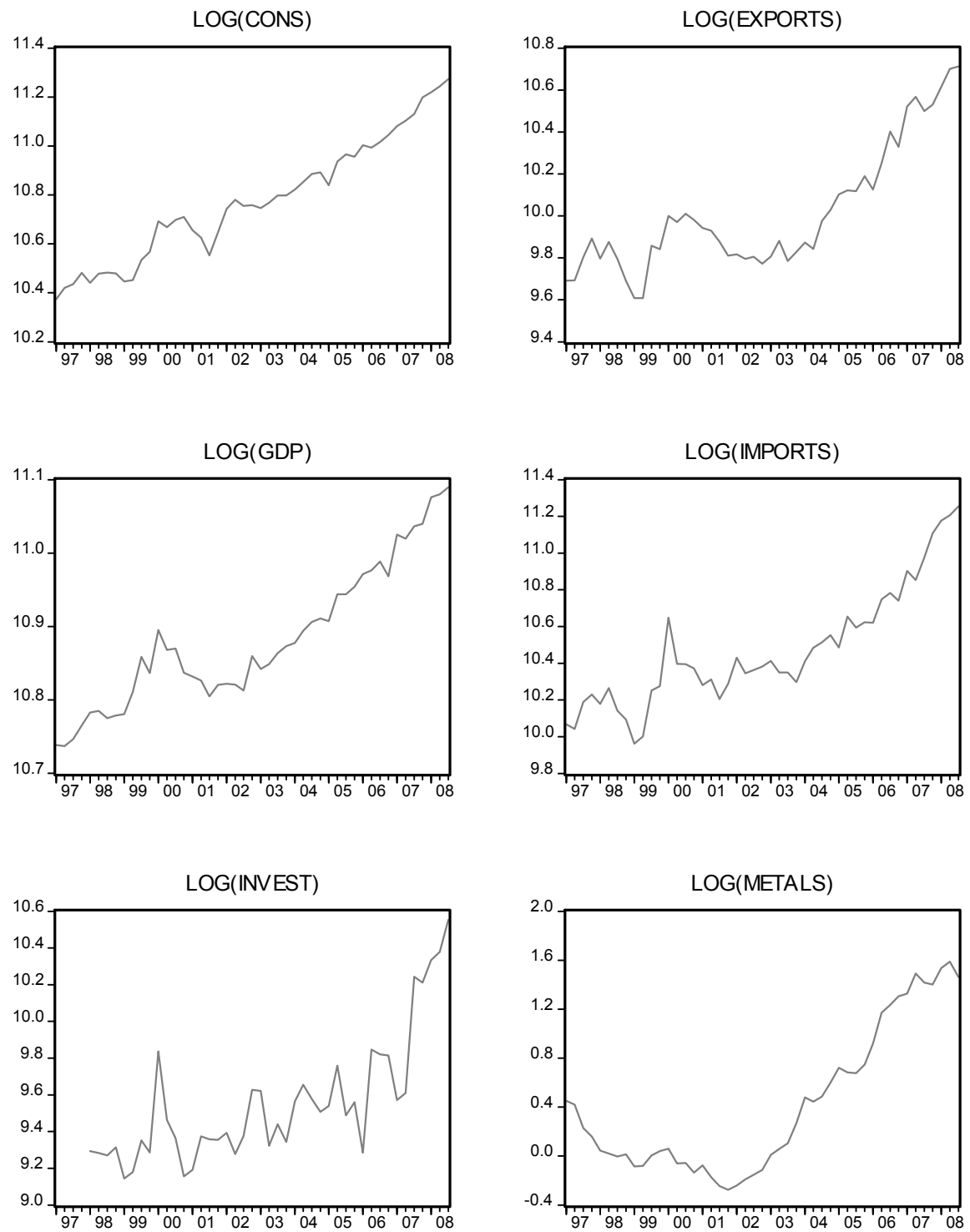

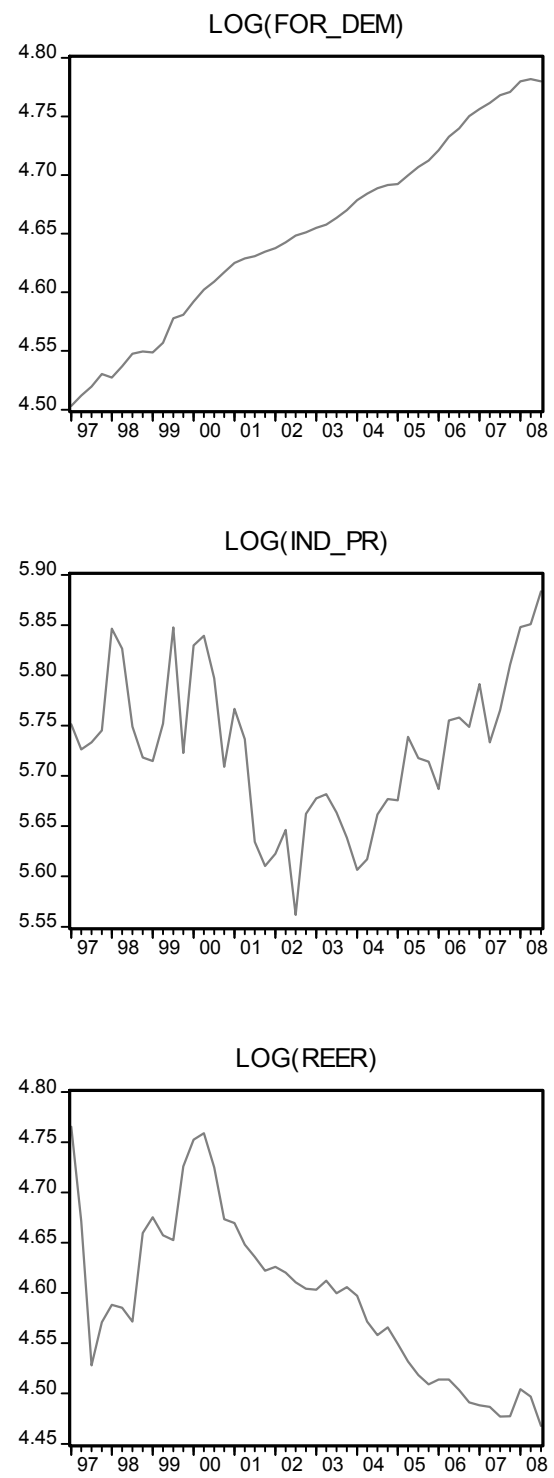
Figure A2 - Plots of the residuals from the OLS exports and imports models

RESID_EXP_1

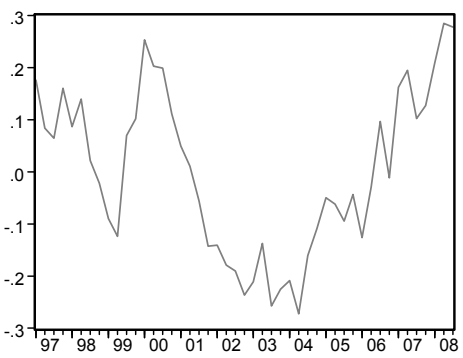

RESID_EXP_3

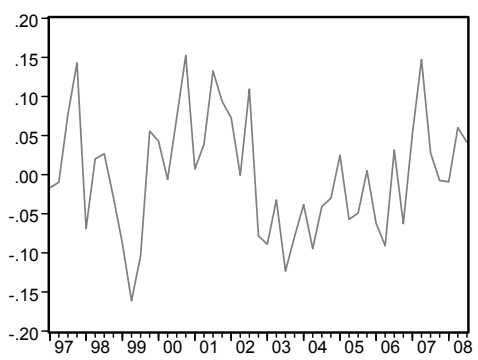

RESID_IMP_1

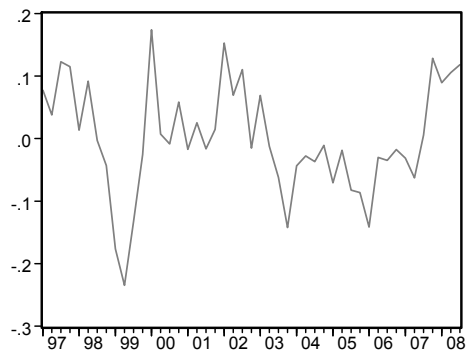

RESID_IMP_3

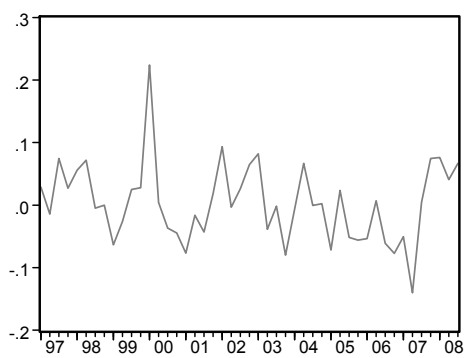

RESID_EXP_2

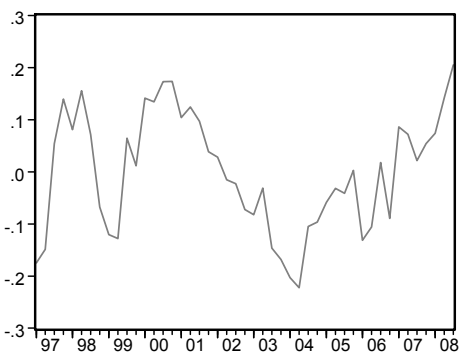

RESID_EXP_4

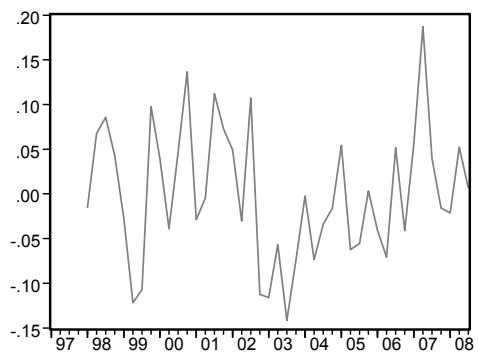

RESID_IMP_2

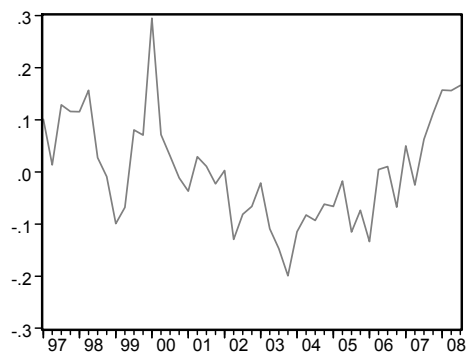

RESID_IMP_4

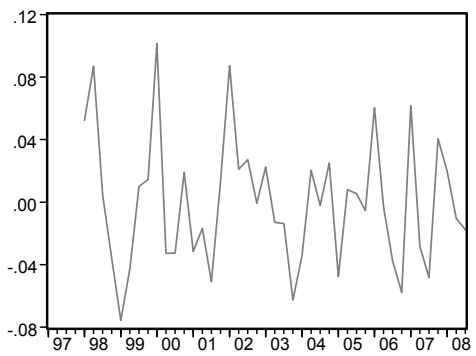


Table A1: Probability values of Chow tests for the exports and imports equations Ho: No structural break in Q4 2002

\begin{tabular}{|l|c|c|}
\hline & Exports & Imports \\
\hline Chow breakpoint test & 0.000 & 0.004 \\
\hline Chow forecast test & 0.193 & 0.310 \\
\hline
\end{tabular}

Figure A-3 - CUSUM and CUSUM of squares tests for the exports and imports
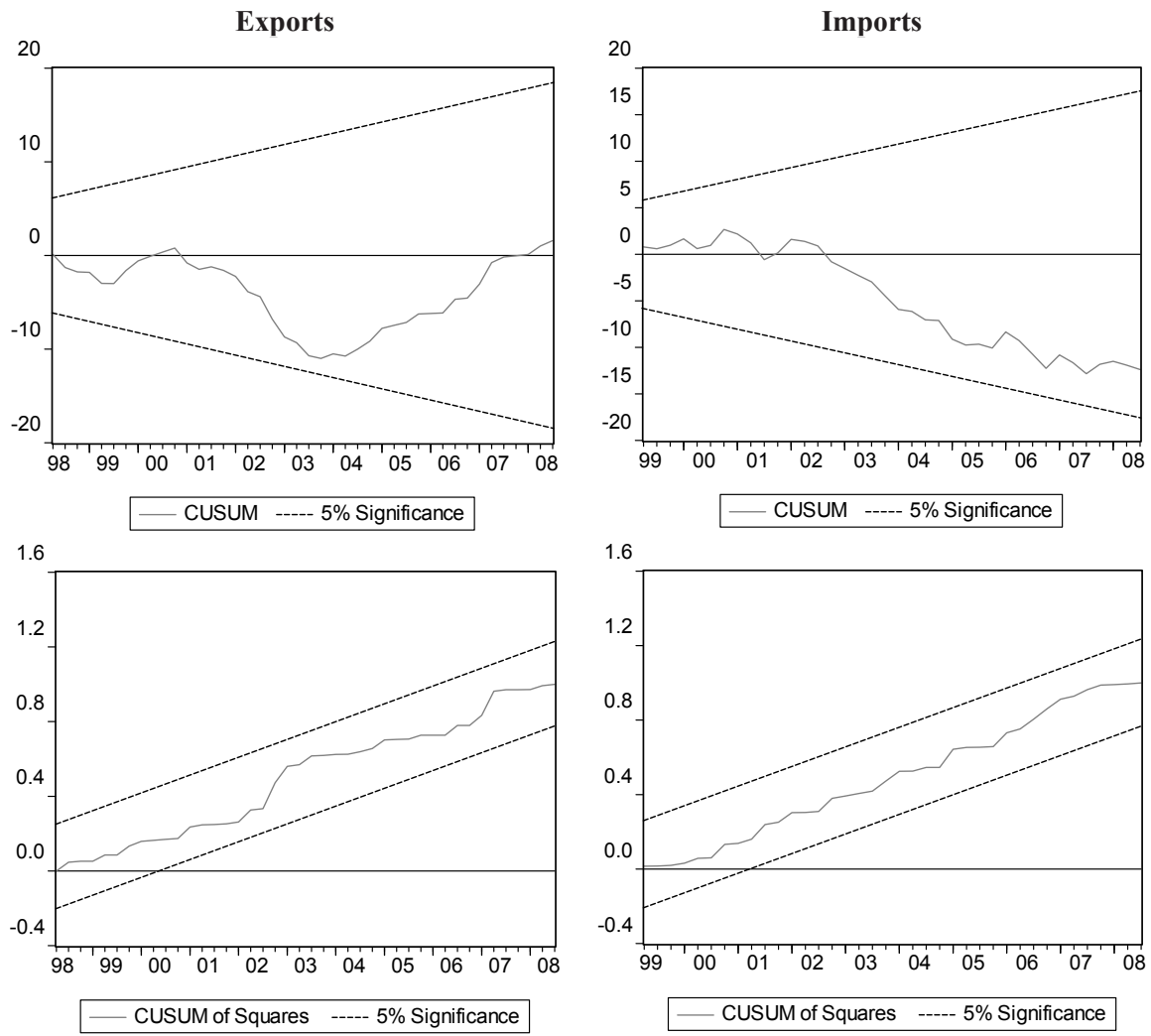
Table A2 - Unit root tests of the levels of the series

\section{Ho: Series has a unit root}

\begin{tabular}{|c|c|c|c|c|}
\hline Series & Test & Test statistics & $\begin{array}{c}1 \% \text { critical } \\
\text { value }\end{array}$ & $\begin{array}{l}5 \% \text { critical } \\
\text { value }\end{array}$ \\
\hline \multirow[t]{3}{*}{ Exports } & $\mathrm{ADF}$ & 1.26 & -3.57 & -2.92 \\
\hline & ADF-GLS & 1.70 & -2.61 & -1.95 \\
\hline & Phillips-Perron & 1.69 & -3.57 & -2.92 \\
\hline \multirow[t]{3}{*}{ Imports } & $\mathrm{ADF}$ & 2.15 & -3.57 & -2.92 \\
\hline & ADF-GLS & 2.51 & -2.61 & -1.95 \\
\hline & Phillips-Perron & 1.81 & -3.57 & -2.92 \\
\hline \multirow[t]{3}{*}{ REER } & $\mathrm{ADF}$ & -2.71 & -3.56 & -2.92 \\
\hline & ADF-GLS & -0.15 & -2.61 & -1.95 \\
\hline & Phillips-Perron & -2.72 & -3.56 & -2.92 \\
\hline \multirow[t]{3}{*}{ Foreign demand } & $\mathrm{ADF}$ & -1.58 & -3.57 & -2.92 \\
\hline & ADF-GLS & 0.20 & -2.61 & -1.95 \\
\hline & Phillips-Perron & -1.69 & -3.57 & -2.92 \\
\hline \multirow[t]{3}{*}{ Metals prices } & $\mathrm{ADF}$ & -1.23 & -3.57 & -2.92 \\
\hline & ADF-GLS & -1.47 & -2.61 & -1.95 \\
\hline & Phillips-Perron & 1.14 & -3.60 & -2.93 \\
\hline \multirow{3}{*}{$\begin{array}{l}\text { Industrial } \\
\text { production }\end{array}$} & $\mathrm{ADF}$ & -2.68 & -3.55 & -2.91 \\
\hline & ADF-GLS & -1.84 & -2.61 & -1.95 \\
\hline & Phillips-Perron & -2.60 & -3.55 & -2.91 \\
\hline \multirow[t]{3}{*}{ GDP } & $\mathrm{ADF}$ & 1.24 & -3.58 & -2.93 \\
\hline & ADF-GLS & 2.14 & -2.62 & -1.95 \\
\hline & Phillips-Perron & 0.90 & -3.58 & -2.93 \\
\hline
\end{tabular}




\begin{tabular}{|l|l|c|c|c|}
\hline Series & Test & Test statistics & $\begin{array}{c}\mathbf{1} \% \text { critical } \\
\text { value }\end{array}$ & $\begin{array}{c}\mathbf{5} \% \text { critical } \\
\text { value }\end{array}$ \\
\hline \multirow{3}{*}{$\begin{array}{l}\text { Private } \\
\text { consumption }\end{array}$} & ADF & 1.59 & -3.56 & -2.92 \\
\cline { 2 - 5 } & ADF-GLS & 2.96 & -2.61 & -1.95 \\
\cline { 2 - 5 } & Phillips-Perron & 3.25 & -3.56 & -2.92 \\
\hline \multirow{2}{*}{$\begin{array}{l}\text { Gross } \\
\text { investment }\end{array}$} & ADF & & & -2.94 \\
\cline { 2 - 5 } & ADF-GLS & 0.07 & -2.62 & -1.95 \\
\cline { 2 - 5 } & Phillips-Perron & 1.14 & -3.60 & -2.93 \\
\hline
\end{tabular}

Table A3 - Unit root tests of the first differences of the series

Ho: Series has a unit root

\begin{tabular}{|c|c|c|c|c|}
\hline Series & Test & Test statistics & $\begin{array}{l}1 \% \text { critical } \\
\text { value }\end{array}$ & $\begin{array}{l}5 \% \text { critical } \\
\text { value }\end{array}$ \\
\hline \multirow[t]{3}{*}{ Exports } & $\mathrm{ADF}$ & -7.59 & -3.57 & -2.92 \\
\hline & ADF-GLS & -7.63 & -2.61 & -1.95 \\
\hline & Phillips-Perron & -7.56 & -3.57 & -2.92 \\
\hline \multirow[t]{3}{*}{ Imports } & $\mathrm{ADF}$ & -8.61 & -3.57 & -2.92 \\
\hline & ADF-GLS & -8.64 & -2.61 & -1.95 \\
\hline & Phillips-Perron & -8.46 & -3.57 & -2.92 \\
\hline \multirow[t]{3}{*}{ REER } & $\mathrm{ADF}$ & -3.25 & -3.57 & -2.92 \\
\hline & ADF-GLS & -3.25 & -2.61 & -1.95 \\
\hline & Phillips-Perron & -5.96 & -3.56 & -2.92 \\
\hline \multirow[t]{3}{*}{ Foreign demand } & $\mathrm{ADF}$ & -4.93 & -3.57 & -2.92 \\
\hline & ADF-GLS & -4.90 & -2.61 & -1.95 \\
\hline & Phillips-Perron & -4.96 & -3.57 & -2.92 \\
\hline
\end{tabular}




\begin{tabular}{|c|c|c|c|c|}
\hline Series & Test & Test statistics & $\begin{array}{l}1 \% \text { critical } \\
\text { value }\end{array}$ & $\begin{array}{l}5 \% \text { critical } \\
\text { value }\end{array}$ \\
\hline \multirow[t]{3}{*}{ Metals prices } & $\mathrm{ADF}$ & -1.61 & -3.57 & -2.92 \\
\hline & ADF-GLS & -1.43 & -2.61 & -1.95 \\
\hline & Phillips-Perron & -5.22 & -3.56 & -2.92 \\
\hline \multirow{3}{*}{$\begin{array}{l}\text { Industrial } \\
\text { production }\end{array}$} & $\mathrm{ADF}$ & -9.05 & -3.55 & -2.91 \\
\hline & ADF-GLS & -8.11 & -2.61 & -1.95 \\
\hline & Phillips-Perron & -9.33 & -3.55 & -2.91 \\
\hline \multirow[t]{3}{*}{ GDP } & $\mathrm{ADF}$ & -9.71 & -3.58 & -2.93 \\
\hline & ADF-GLS & -9.34 & -2.62 & -1.95 \\
\hline & Phillips-Perron & -9.29 & -3.58 & -2.93 \\
\hline \multirow{3}{*}{$\begin{array}{l}\text { Private } \\
\text { consumption }\end{array}$} & $\mathrm{ADF}$ & -6.76 & -3.56 & -2.92 \\
\hline & ADF-GLS & -6.76 & -2.61 & -1.95 \\
\hline & Phillips-Perron & -6.76 & -3.56 & -2.92 \\
\hline \multirow{3}{*}{$\begin{array}{l}\text { Gross } \\
\text { investment }\end{array}$} & $\mathrm{ADF}$ & -7.75 & -3.60 & -2.94 \\
\hline & ADF-GLS & -7.85 & -2.62 & -1.95 \\
\hline & Phillips-Perron & -7.77 & -3.60 & -2.94 \\
\hline
\end{tabular}

Table A4 - Results of the unit root tests for the residuals of the exports and imports regressions

\section{Ho: Residuals have unit root}

\begin{tabular}{|l|c|c|}
\hline & $\begin{array}{c}\text { Exports } \\
\text { (Eq. 4 from Table 2) }\end{array}$ & $\begin{array}{c}\text { Imports } \\
\text { (Eq. 4 from Table 3) }\end{array}$ \\
\hline Dickey-Fuller test statistics & -4.02 & -5.68 \\
\hline $5 \%$ critical value & -4.76 & -4.76 \\
\hline
\end{tabular}

